\title{
Heresy and Authority: Understanding the turn against Ahmadiyah in Indonesia.
}

\author{
JACQUELINE HICKS \\ Koninklijk Instituut voor Taal-, Land-en Volkenkunde (KITLV), Leiden, Netherlands.
}

\begin{abstract}
This article adds to the literature explaining a rise in the levels of violence and intimidation against the Islamic sect Ahmadiyah in Indonesia. In contrast to approaches which stop at describing the actors or doctrinal differences involved, this article situates the anti-Ahmadiyah discourse in wider processes of maintaining or securing political and social authority. The first section describes the ways in which charges of heresy have historically served to consolidate state and political authorities. It then extends this analysis into the post-Soeharto landscape by showing how the charges of heresy against Ahmadiyah have supported fragments of the New Order state to claw back some of the authority which was lost following the 1998 political transition. The third section then situates this process in the context of increased competition among religious authorities. The implications of using such an approach are that (1) the Indonesian state's role in the conflict is not just defined by its absence, but also by its active involvement (2) understanding the rise of conservative ulamas as part of a wider process of an increase in many different voices weakens the claim that Indonesia is becoming more religiously conservative. The more general conclusion is that the role of academic writing should be to contextualize contemporary discourses of heresy by revisiting some of the methods used in classic heresiology.
\end{abstract}

KEY WORDS: Ahmadiyah (Ahmadiyya); Indonesia; Heresy; Religious Authorities; Islam.

Acknowledgements: The author would like to thank Jajat Burhanudin, Herdi Sahrasad, Johan Purnama, Muhomod Chozin and Azyumardi Azra for their valuable insights in discussing this article.

\section{Introduction}

It is surprising to hear so few mainstream religious voices speak in defense of the Islamic sect, Ahmadiyah's, right to worship in a tolerant country like Indonesia. While the leaders of the country's largest Muslim organizations, Nahdlatul Ulama (NU) and Muhammadiyah, unequivocally condemn the use of violence against Ahmadis, there has been a good deal of support for their forced disbanding. ${ }^{1}$

\footnotetext{
${ }^{1}$ The range of opinions coming out of these massive organizations about Ahmadiyah is extremely diverse. The official line from their central committees is that the decision to ban Ahmadiyah is in the hands of the government (Silitonga, 2011). Yet many senior leaders have publicly supported a ban at both the central or regional level (Anonymous, 2011a; Anonymous, 2011b). See also Platzdasch, 2011, pp.18-19.
} 
For many mainstream Muslims, accepting Ahmadiyah's right to exist means accepting the sect's claim that Muhammad was not the last prophet - something which has the potential to undermine their own faith. For, unlike Indonesia's other religious minorities, Ahmadiyah's case seems to be a theological "zero sum game" where their beliefs cannot co-exist with those of other Muslims.

Most analyses of the violence and intimidation experienced by Ahmadis describe these competing theological claims and the fundamentalist groups which activate them. The government approach is well represented by an article written by the Head of Research at the Department of Religion, which simply records the theological differences of religious "splinter groups", presenting the government's stance as a rational response to these (Masud, 2009; see also Nasution, 2008). Most mainstream media reporting of the issue similarly focuses on the theological claims as the basis of conflict. Meanwhile, non-governmental organizations and foreign think-tanks produce research describing the fundamentalist groups and individuals involved in fomenting anti-Ahmadiyah sentiment (Setara, 2010; LBH/ Kontras, 2008; ICG, 2008). Most academic research to date takes a similar approach, looking at the Ahmadiyah issue within the context of unclear laws and state bodies neglecting their duty to uphold human rights (Platzdasch, 2011; Colbran, 2010; Crouch, 2009).

These analyses correspond with two different approaches in the wider academic literature, which I label "religious essentialism" and "political instrumentalism." The instrumentalist interpretation of religious-based persecution sees such actions as driven by elites - opportunists who cynically manipulate religious texts or imagery to gain personal power. What I have called "religious essentialism" puts theology at the centre of the analysis by highlighting particular passages of holy texts that seem to demand action.

While the literature on the persecution of Indonesian Ahmadis described above is more complex than these two categories suggest, they nevertheless share some of their problematic assumptions and implications. Few people today would try to defend an exclusive commitment to the religious essentialist approach. Searching the Koran to reference sections which explain the importance of accepting Muhammad as the last prophet, or the acceptance or denial of religious diversity is in some ways worthwhile. As Foucault, and others, has shown, words have their own power under any circumstances, let alone when they are imbued with religious significance in a book as holy as the Koran, and understanding their discourse is essential. But highlighting parts of scriptures without a corresponding attempt to understand the relationship between the text and the interpreter is unhelpful and misleading. Sometimes known as the "aesthetics of reception," we must move beyond a description of the words in a text if we are to explain their meaning to the people who use them. To do this, we must first understand the basis of an individual's power to interpret and assert the text while at the same time considering the historical context in which it gains life. 
In some ways, political instrumentalism is the opposite of religious essentialism. By showing the ways that religious symbols are used by unscrupulous political elites, it usefully avoids presenting a whole religion as intrinsically "bad," but it also has some uncomfortable implications. If it is really all about the personal ambitions of particular leaders, then the religious component is relegated to serve as nothing more than a marker for the real concern which is usually political or economic. It also leaves us in the difficult position of proclaiming the professed beliefs of some leaders or followers as somewhat fake.

The central question of this article is to look at why there has been a growing upsurge in agitation against Ahmadiyah in Indonesia in the last five years in particular? Ostensibly, it is difficult to understand why Ahmadiyah should be seen as a threat. It is a relatively small sect of approximately 400,000 people in an overall population of 250 million. It has been largely irrelevant to the exercise of both political and economic power and has existed inside Indonesia since 1925 with only sporadic problems. Certainly, as the current literature shows, Ahmadiyah is the victim of a small set of fundamentalist Islamic groups with powerful lobbying connections in government. But how can we explain these fundamentalisms and the state's response to them?

In order to answer these questions, this article offers an interpretive framework which tries to avoid underplaying political power (as religious essentialism) or religion (as political instrumentalism). Instead of taking a position on these polemics, it looks at the ways the anti-Ahmadiyah discourse has played into wider processes of maintaining or securing both political and religious authority. I do not deny the agency of particular actors - indeed all the usual players from politically ambitious ulamas to members of state organisations and other religious leaders populate the analysis. Rather, the goal of this article is to draw closer attention to the dynamics of power and authority which surround them.

The first section begins by showing how charges of heresy have historically been used in Indonesia to consolidate a centralizing political authority. It then applies this insight to the current situation, detailing the ways in which fragments of the New Order state have been strengthened by the Anti-Ahmadiyah controversy. The third section re-focuses on the religious sphere by examining the dynamics of competition among religious authorities.

\section{A Brief History of Heresy and Political Authority}

There is much evidence to support those who frame the problems faced by Ahmadiyah in terms of theological doctrine alone. For, despite very big differences in socio-political contexts since its arrival on Indonesian soil in 1925, there has been some continuity in the types of reaction the sect has occasionally received from parts of the religious community over the years. While Ahmadi ulamas have always been able to have good relations with some non-Ahmadi ulamas (Zulkarnain, 2005: 247; 
$273 ; 293)$, its history has been constantly dogged by theological contention. Thousands of people attended forums to debate Ahmadiyah's beliefs about the prophet Muhammad in the 1930s and 1940s, while the mainstream Muslim organisations, Muhammadiyah and NU, took official stances against the sect in 1927 and 1938 (Burhani, 2012). Even during Soeharto's reign, when it is widely believed that Ahmadiyah was somewhat protected by the military regime's preparedness to suppress any signs of conflict, there were strong echoes of its current predicament. Although generally unreported in the mainstream Indonesian media, at least some cases of anti-Ahmadiyah violence were recorded in 1969, 1976 and 1981 (Muryadi, 2005: 86) as well as instances of local attorney generals issuing regulations outlawing the spread of Ahmadiyah teachings (Purwanto, 2008: 80). One 1987 case of an Ahmadi village head replaced by an official prepared to restrict Ahmadiyah activities shows the likely way that the New Order dealt with any potential conflict on the issue (Rosidin, 2010: 18).

However, while the theological differences are real, they are not sufficient to produce an active discourse of heresy. For that to occur, the heretical status of an articulated opinion relies on the "institutionalized legitimation" of the discourse within which the heresy is voiced (Zito, 193: 125). In Indonesia's case, this legitimation has historically been provided by the political authority of a/the state through a process which reveals how some versions of Islam became embedded in Indonesia's social and political landscape.

Islam began to spread throughout the Indonesian archipelago from the fourteenth century onwards by traders and Sufis - adherents of a mystical form of Islam (Ricklefs, 2008: 4-5). In the following centuries, the rate of conversion picked up pace in the coastal regions in particular as local rulers adopted Islam. The possible reasons why Islam became so attractive to the rulers are various. They range from the spiritual (a genuine shift in personal belief) to the material (to ease the path of trade with Muslim traders), to the strategic (to consolidate power in monarchical Islamic forms and forge political alliances) and the symbolic (to appropriate the prestige of the magical forms of Islam) (Reid, 1993; Reid, 1995; Ricklefs, 1979; Azuymardi, 2006).

The ways that Islam was subsequently absorbed into, and changed the character of, existing structures of socio-political power over the centuries is the subject of a large body of scholarship produced by some of the leading scholars of Indonesian history. ${ }^{2}$ For the purposes of this article, I will confine the analysis to show how the charge of heresy was used to consolidate a centralized political authority in three episodes hundreds of years apart.

The first episode reaches back to the fifteenth and sixteenth centuries where the lack of contemporaneous historical records has led historians to partially rely on Javanese legends. While these were written in the seventeenth or eighteenth centuries, they

\footnotetext{
${ }^{2}$ See, for example, many works by Anthony Reid, Merle Ricklefs, Martin Van Bruinessen, Azuymardi Azra.
} 
nevertheless have some value in reflecting how later generations of Indonesian Muslims saw the early process of Islamisation (Ricklefs, 2008: 13). One set of manuscripts in particular (Bada Tanah Jawi) tells the story of nine saints (wali sanga) who are said to have been at the forefront of the first wave of Islamic conversion. Each saint's teaching is depicted as being both mystical and unique, their names carry Javanese honorifics (sunan) as well as Arabic (wali) and there is no emphasis on outward Islamic symbols, such as a sudden circumcision. These points all indicate that their story reflects the diversity of early Javanese Islam and its assimilation with local beliefs (Ali, 2008; Ricklefs, 2008).

Nevertheless, there is an important episode where one of the wali sanga, Sunan Sitijenar, is accused by the others of heretical teachings and executed. This well known story is often couched in terms of theological contention where Sitijenar's more syncretic teachings are compared to the orthodox, although still mystical, teachings of the other wali sangas. Yet the manuscripts which describe the conflict (Babad Jaka Tingkir) talk little of the actual substance of the teachings, focusing instead on his sin of "baring the Knowledge" - the esoteric spiritual and mystical wisdom of Islam - to the populace. After careful reading of these texts, it becomes clear that the danger that Sitijenar embodies is not an alternative interpretation of Islamic doctrine. Rather, his populist dissemination of "the Knowledge" marks him as an opponent of the centralization and unification of authority which the wali sangas achieved through their relationship with the supreme political institution of the time - the royal court of Demak (Florida, 1995: 356 - 359; Ricci, 2011: 200).

In the following centuries more royal courts adopted Islam and appointed ulamas as advisors although their actual level of influence varied considerably from place to place (van Bruinessen, 1995). Inevitably, as Islam became more strongly identified with royal courts, elite or state military conflicts sometimes became couched in religious terms. But accusations of heresy could also consolidate a ruler's power even when the accused were no practical threat to the throne.

One such example is from the mid seventeenth century when an Indian-born ulama, Al Raniri, became a close advisor to the Sultan of Aceh, Iskandar Thani. A welleducated scholar, Al Raniri spent much of his seven years in Aceh writing tracts against what he saw as the heretical ideas of two well known Sufis - Hamzah and Shams al Din. His writings heavily criticised these Sufis' idea that the individual Muslim could realize his essential union with the Creator, which Al Raniri thought implied that human effort could unlock the secrets of the divine unity (Riddell, 2001: 120-121). Al Raniri won a debate with Hamzah and Shams al Din before the Sultan and the 'heretics', with many of their followers, were put to death. But, as Riddell points out, Al Raniri's accusations were aimed at stressing the differentiation between God and his earthly manifestations, which ultimately implied that ordinary individuals should acknowledge the authority of the sultan as head of the temporal kingdom (124). In this way, Al Raniri's accusations of heresy served the consolidation of the Sultan's political power very well indeed. 
As European colonialism began to disrupt trade networks, the fortunes of the Islamic kingdoms waned. The royally appointed ulamas lost their proximity to political power and many renewed their focus on establishing their own institutions of learning outside of the royal domain (Burhanudin, 2005). As the Dutch continued to strengthen their political control, ulamas were generally sidelined into the rural areas. Some were absorbed into a new corps of religious bureaucrats (penghulu) who ran religious courts and mosques, but generally lacked the legitimacy of the rural ulamas (Lev, 1972: 11). The Dutch strategy of marginalization and delegitimisation also included the cooption of some well-known ulamas. Laffan relates how one such ulama, Said Oesman, was given a government post as Honorary Adviser on Arab Affairs in the last decades of Dutch rule where he had a base from which he could "prosecute his campaigns against what he saw as local innovation and heresy." (p.87) Social stability was paramount for the Dutch as they pursued the economic extraction of the East Indies and allowing a trusted ally the authority to be an arbiter of religious orthodoxy was one way to dampen the potential of religiously based social movements.

The last decades of Dutch control were a time of great turmoil. Islamic symbols were increasingly used to mobilize the population against colonial rule, crystallized with the formation of the first mass Islamic organization, Sarekat Islam, around the turn of the $20^{\text {th }}$ century. Ulamas were involved in the communist uprisings of the 1920s in Banten and Minangkabau and later in the militia group Darul Islam in the turbulent years that accompanied Indonesia's independence. Some Ahmadis who lived through Darul Islam's campaign in the 1950s report being targeted by the group, but in the context of tens of thousands of deaths and extreme political flux, this is perhaps not surprising. It was not until the political situation stabilised under the Soeharto rule and Islam was once again pulled into the orbit of a powerful, central political authority that accusations of heresy again gained currency.

In the religious sphere, the New Order project to manage social, political and economic power was realized through the creation of a council of ulamas (Majelis Ulama Indonesia - MUI). Along with a host of other state controlled organizations, MUI's members were expected to be compliant with government opinions and high level bureaucrats sat on their board (Porter, 2002: 78).

In addition to other tasks, such as the development of Islamic community organisations and preaching, MUI issued opinions and recommendations with varying degrees of formality. Over the years, the subjects of these opinions have been diverse indeed, ranging from medical matters to food to technology, with at least eight related to heretical sects. In addition to Ahmadiyah, Shi'ism, Islam Jamaah, Darul Arqam, Inkar Sunnah, and Salamullah are some of the other Islamic groups which were declared heretical since MUI's establishment in 1975.

Evidently, a council of ulamas which is more or less under the control of the state will support that state's authority in many different ways, but the general purpose of assigning arbiters of religious orthodoxy (and by extension heresy) is social and 
political control. Indeed, the state apparatus today used against sects like Ahmadiyah - the watchdog of deviant faiths Bakor Pakem and the 1966 law on blasphemy - were first used as tools to help eradicate communism. In those days, Bakor Pakem and the Department of Religion kept watch not on Muslim splinter groups, but on Indonesian religions known collectively as aliran kepercayaan, producing secret periodical reports detailing their activities. The New Order considered these small indigenous religions to be potential resting places for those with communist beliefs and banned hundreds of them during the 1960s and 1970s (Patty, 1986: 93). This echoed the colonial government's preoccupation with local religions such as Saminism as sources of social disorder (Benda and Castles 1969).

As the New Order defined what could be considered a religion, MUI became the officially sanctioned arbiter of Islamic orthodoxy. As Porter points out, this served the "state's interests in maintaining stability, countering autonomous Islamic organization and political movements that could disturb stability and security" (2002: 79). On the ground, it amounted to some MUI members gathering intelligence on "deviant religious tendencies," but, echoing the pre-colonial examples, the attention to heresy also served to support the "cultural and mental" hegemony of the New Order state more generally (Olle, 2009: 105).

\section{Heresy in an Era of Democratisation}

As the institutional landscape changed once again in 1998 and political power fragmented both within and between national and local levels, so there have been changes in the ways that the twin religious and political authorities interact around charges of heresy. In some ways, democratisation and decentralisation now enable individual ulamas to bypass a central political authority to use the heresy accusations to bolster their individual powerbases.

There is a whole spectrum of proximity in the relationships between anti-Ahmadiyah ulama and politicians. Some politicians and parties use the Ahmadiyah controversy in campaigns for election (see Crouch, 2011; International Crisis Group, 2008; Platzdasch, 2011). Regional mayors and governors have ulamas who head their own pesantrens (Islamic boarding school) as close advisors. ${ }^{3}$ (Setara, 2010; 2011). Pesantren leaders gain their political capital from being able to use their students for campaigning or in demonstrations, making them particularly important in local politics where local parliaments and courts can be physically reached easily. Without a pesantren, other ulamas alternate between a few years in the regions preaching in mosques and community meetings and then as an elected politician in Jakarta. Sometimes they will change allegiances to different political parties, whether Islamic or nominally secular. They are clearly politicians, but they are also referred

\footnotetext{
${ }^{3}$ An anti-Ahmadiyah platform is not always a vote-winner, even in what is considered fertile ground. For example, one well-known mayor of Cianjur, Wasidi, was not able to get re-elected after he made the issue central to his campaign (Mudzakkir, 2007).
} 
to by the honorific ulama, ajengan or ustadz both by newspapers and online publications as well as those they preach against.

In the popular imagination, the demise of state control that accompanied the 1998 democratic opening allowed the resurgence of the type of Islamic constituency concerned with heresy. As one journalist puts it, the overthrow of Soeharto "blew the lid off the pressure cooker of Indonesian radicalism" (Aglionby, 2005). While it is true that the most vociferous radical groups, such as FPI (Front Pembela Islam) and GARIS (Gerakan Reformis Islam), found new freedom to organise and lobby in the post-Soeharto period, such an analysis neglects an important part of the story - the crucial role of New Order functionaries and groups.

In the same way that charges of heresy supported the consolidation of state authorities historically, so fragments of the New Order state, especially at the local level, have clawed back some of their previous authority through their involvement in the current anti-Ahmadiyah actions. This section will first highlight some of the bureaucratic and military bodies involved in the maintenance of New Order political and social authority. It will then take these bodies through the period after 1998 as they struggle to maintain institutional relevance, before showing how they have been revived by the Ahmadiyah issue.

During the New Order, the bureaucratic and military leaders who ruled at the local level derived much of their authority from the central state. Governors and Bupatis were handpicked from Jakarta, and a state agency - the Directorate for Social and Political affairs - represented the central government's interests at both provincial and district levels. Bureaucrats from this directorate held the right to determine the legality of organizations, issue permission for political activities and screened the recruitment of all civil servants (Buchori and Lay, 2000: 15). As some have pointed out, the New Order state was never the coherent totalitarian power it tried to project, but was fragmented, often overwhelmed and sometimes ineffective (Barker and van Klinken, 2009: 23). Nevertheless, in the absence of any meaningful political power from the local legislatures or indeed civil society, the central government monopolized decision making in the regional polity.

Military involvement in local structures of power and authority was pervasive. The Directorate for Social and Political affairs was largely controlled by active military personnel and the omnipresent military units at all levels of local administration contained a whole raft of official bodies specifically aimed at social and political surveillance. ${ }^{4}$ It was not unusual for Bupatis or Governors to be from the military,

\footnotetext{
${ }^{4}$ For example, Central Political and Social Council (Wansospolpus); Provincial Political and Social Council (Wansospolda); Kamtibmas (Coordinating Body on Assistance for National Stability); Functional Guidance Body (Babinkar); Political and Social Staff (Syawan) Command for the Restoration of Stability and Order (Kopkamtib) and its successor the National Stability Coordination Board (Bakorstanas). (Tanter, 2000; Bhakti et al, 2009).
} 
and more informal relationships between military personnel, local politicians and criminals served to further cement military control.

Religious expression was regulated by a number of state bodies. The Ministry of Religious Affairs ensured that dakwah (preachings) were broadly "pro-state, proPancasila and pro-development." If necessary, police and military forces could be used as back-up to press the point home to any ulamas who deviated from this message (Ichwan and Meuleman, 2002: 38). As already mentioned, "the hand of government" (Hooker, 2003: 235) was often visible in the decisions of the ulama grouping, MUI.

In addition, a different organisation, Bakor Pakem (Badan Koordinasi Pengawas Aliran Kepercayaan Masyakarat), was created especially to monitor religious minorities whose teachings deviated from "mainstream religions." It has existed in some form under the roof of the Attorney General's Office since the 1960s, gaining a stronger legal basis and the support to open branches in the regions in 1994. It is headed by the Attorney General and has members drawn from the military and civil intelligence community, the Departments of Religion, Culture and the Directorate of Social and Political Affairs, as well as military and police and religious leaders (Sihombing, 2008: 46). Like MUI, it has a national headquarters and regional branches and was relatively active in the late New Order period in particular in issuing recommendations to ban "deviant" sects.

As the New Order lost its head with Soeharto's downfall in 1998, and rapid institutional change ensued in the first five years of the reformasi period, this 'superstructure' of control and surveillance was thrown into some disarray. Decentralisation devolved a whole host of new authorities to the regions, political liberalisation gave local parliaments much more power and the military accepted an ideological sea-change drastically curtailing their involvement in social and political affairs.

Little was heard from the Bakor Pakem from 1998 until 2005, leading one research report to describe it as effectively "moribund" during that time (ICG, 2008: 3). Despite declaring that it was now a "servant of the Muslim community" rather than a "servant of the government" in 2000 (Ichwan, 2011: 212), MUI had particular problems in the immediate reformasi period of regaining the legitimacy it had lost as a result of its involvement with the New Order. At a time when MUI had to respond to a sudden proliferation of new leaders and groups purporting to represent Muslims, it struggled to find a role which would be relevant to the new political and social context (Gillespie, 2007; Ridho, 2008).

Meanwhile, the military lost many of its official bodies tasked with involvement in the social and political arenas (Bhakti, 2009: 9). The regional, district, and subdistrict social and political staff commands of the military were abolished and the military factions in the national, provincial and district parliaments were phased out. Official organisational relations between the military and the Golkar party were 
severed and, officially, equal relations were maintained with all parties (Bhakti et al, 1999: 139). While social and political affairs offices continue to maintain their structural relations with central government to the present day, political power has now largely moved from the local bureaucracy to the local parliament (Lay 2000: 19) and although some bureaucrats maintain their political and social authority, it is no longer automatically derived from their connection to central government.

No matter what institutional configuration holds them, the people involved in all of these groups were always likely to hold some degree of residual personal power. Nevertheless, it is remarkable how the issue of heresy generally, and Ahmadiyah in particular, has served the interests of all of these bodies, conferring them with new levels of authority and substantially raising their profile.

At the local level, MUI and Bakor Pakem work closely together on the issue of "deviant sects," with Bakor Pakem using MUI opinions in their recommendations which are then passed on to be implemented by the AGO and/or an adhoc body responsible for security coordination called Muspika at the kabupaten level, and Muspida at the provincial level (Sihombing, 2008: 57; Ali, 2007).

In the first flush of reformasi with Habibie as president, MUI's publicly issued formal opinions (tausiyahs and fatwas) were broadly supportive of the president, focusing on subjects as various as a corruption scandal, the general elections, and the conflicts in Ambon and East Timor (Ichwan, 2005). However, during the Wahid and Megawati presidencies, MUI's opinions became more confrontational. An always strained relationship between MUI and Wahid became even worse as Wahid suggested that the body should no longer receive any government funding. Among other issues, the president's policies on opening trade to Israel and overturning the ban on Communism provoked strong opposition by MUI (Ichwan, 2005). There was also a good deal of provocation from MUI towards Megawati, particularly over her initial refusal to condemn US bombings of Afghanistan.

Although heresy had been identified as a priority by a MUI national congress in 2000 , there was no real action on the issue until 2005. MUI's strategy of directly engaging with the daily cut and thrust of government policies in the first five years of reformasi had made it vulnerable to political change. But with its renewed focus on heresy from 2005 onwards, it made something of a return back to the role it had served during the New Order period - that of maintaining "social cohesion" and defining religious orthodoxy. It had re-discovered a niche for itself that didn't have to involve such a combative stance with the top political elite.

With a much narrower mandate than MUI, Bakor Pakem's revival was always going to depend on a rise in charges of heresy. As an ad hoc body, its activities had always been somewhat sporadic and locally driven. According to one source at the Attorney General's Office, the national headquarters of Bakor Pakem has never made any recommendations itself about any deviant sects, only dealing with those made by its regional offices (Ali, 2007). There do not appear to be any documents 
detailing the activities of the body, so it is difficult to say exactly how "moribund" it had become in the first few years of reformasi, but a search of newspaper stories shows a sudden rise of citations from 2008 onwards as it became involved in the Ahmadiyah controversy. ${ }^{5}$ In recent years, there have also been a number of newspaper articles from various regions announcing the "re-activation" of local Bakor Pakems, with one local MUI head confirming that the body's activities had not been optimal because it had been suspected of "smelling of the New Order." (Anonymous, 2005).

In some areas, another adhoc body, the Muspida/ Muspika, has also seen a return to its New Order heyday on the back of the Ahmadiyah issue. A body originally formed in 1967 and further legitimized with a presidential regulation in 1986, Muspida is made up of all the top military and bureaucratic power-holders at the regional level, including the mayor or governor, the heads of the regional military and police, the chairperson of the local parliament and Attorney's office. Ostensibly, it is a coordination body for security concerns at the regional level, but in practice during the New Order it was "the most powerful institution in the province" (ex army chief of staff, General Nasution, quoted in Jenkins: 218). It is described elsewhere as a forum where "the most significant political decisions were made" at the local level (Buchori and Lay, 2000: 14).

Legally, the Muspida deals with "threats to stability," but with no further formal guidelines, what constitutes such a threat is open to interpretation. A wide range of issues are dealt with in Muspida meetings, from low security problems like eradicating vice and evicting squatters, to higher threats from terrorism or ethnic conflict (Jansen, 2008: 442). Throughout the 1970s and 1980s in particular, members of the old Darul Islam movement were involved in occasional incidents, including the murder of a university rector and theft. The most high profile case was the hijacking of a Garuda flight in 1981 to demand the release of Komando Jihad prisoners. There is well founded speculation that one of Soeharto's trusted generals, Ali Moertopo, directed some of these members in order to cause insecurity and undermine the appeal of the Islamic political parties at that time (Amal and Panggabean, 2004, pp. 68-71; Mashadi, 2010; Hefner, 2005: 291-292). Muspidas were also involved in pressuring members of Islamic sects or other religious groups outside the permitted five main state religions to disband or renounce their religious beliefs.

The photos below illustrate the continuities in Muspida's role in socio-religious control. On the left is a 1976 photo of people from a local religious sect called Perjalanan converting to Islam at a Muspida meeting. On the right is a photo of Ahmadis converting at a Muspida meeting in 2011. Both are taken in West Java, just $50 \mathrm{~km}$ from each other.

\footnotetext{
${ }^{5}$ A search of citations for "Bakor Pakem" or "Tim Pakem" in Kompas archives from 1965 until 2012 shows six mentions from 1990 until 1993 and then none until there are14 stories in 2008. Of course, this could say more about freedom of the press than Bakor's actual activities.

${ }^{6}$ Keputusan Presiden Republik Indonesia 10/1986 tentang Musyawarah Pimpinan Daerah.
} 


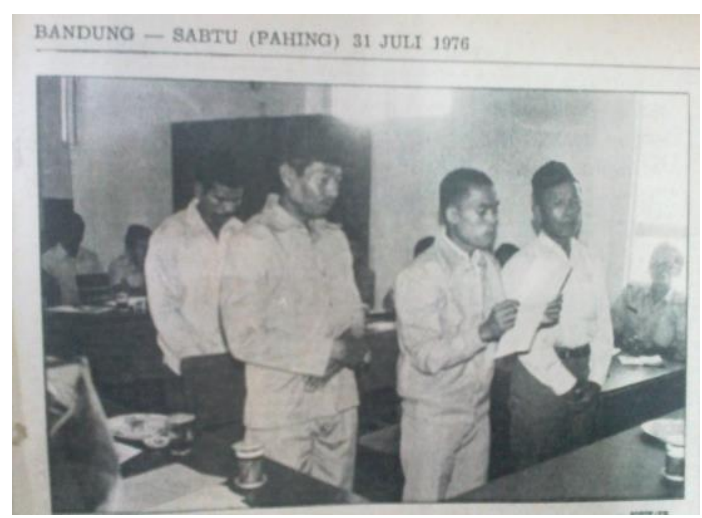

Pikiran Rakyat, July 31, 1976

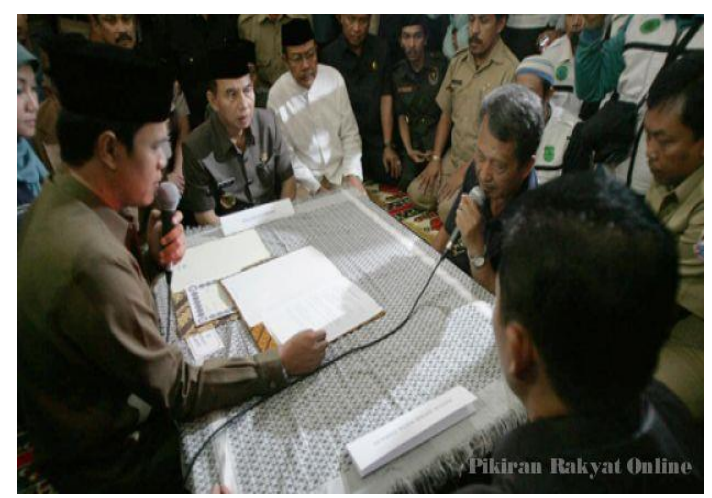

Pikiran Rakyat, March 30, 2011.

As individuals, some military or ex-military personnel have adapted to the new political context of decentralisation and entered into partnerships with local political elites or stood for election themselves (Mietzner, 2006: 57). However, as an institution, the military has lost many of the institutions through which they previously exercised political influence and although Muspidas still exist in many parts of the country, they too have lost some of their authority (Buchori and Lay, 2000: 19). There have also been calls from NGOs for the disbandment of Muspida (Anonymous, 2006) and in some regions there have been controversies over how much their meetings should be funded by the state budget (Ismail, 2010; Hudiyanto, 2011). For those Muspidas which remain active, they are said by some to be one of the few channels through which the military can now exercise a direct influence on local political affairs (Honna 2011: 141).

In most areas where attacks against Ahmadiyah have taken place, they often occur after a process of deliberation involving MUI, Bakor Pakem and the Muspida, in addition to other elements of the local bureaucracy. An unreleased 200 page report by Indonesia's National Human Rights Commission (Komnas Ham) on the deadly Cikeusik incident in 2011 illustrates this well. Starting from at least one year prior to the day of the attack, it records all the many different meetings that were held among members of the military, police, MUI, Bakor Pakem, and some religious leaders under the aegis of Muspikas.

Far from being absent or non-responsive, everywhere where there have been attacks against Ahmadiyah, elements of the military, the local bureaucracy and the state religious organisations, have been very active. Human Rights NGOs have documented many cases of military involvement in Ahmadiyah intimidation, from collecting data on Ahmadi families to pressuring them to convert and taking over Ahmadiyah mosques (Firmansyah, 2011). Local government officials visit Ahmadi families and send letters asking them to attend conversion meetings (Amnesty International, 2011). Bakor Pakem members have issued letters to local government officials instructing them to withhold the official identity cards (KTP) of members of Ahmadiyah (Sihombing, 2008: 39). 
In some cases, military, police or bureaucratic personnel operate directly with the civil society groups which agitate against Ahmadiyah. In others they maintain a relatively neutral stance, seeking to build consensus to avoid violence. Yet, in all cases, the Ahmadiyah issue has revived the relevance of the organisations to which they belong, giving them a reason to exist in the post-New Order context.

\section{Competition among Religious Authorities}

This section takes broad inspiration from the approach used by John Sidel in his book on religious violence around the democratic transition - Riots, Pogroms, Jihad: Religious Violence in Indonesia. Sidel's primary focus is explaining the different types of religious violence which occurred from 1995-2005 as reflections of shifting religious identities and their resultant anxieties (2007: 221). Here, I take the same approach, but expand on Sidel's concern with religious authorities and extend it to the violence against Ahmadiyah. I highlight the proliferation of different sources of religious authorities in the post-Soeharto era, arguing that it forms the unstable context within which the Ahmadiyah issue has become a useful way for religious leaders to distinguish themselves and claim more authority.

Following Kaptein (2004: 115), it is useful to distinguish between the different types of religious authority, which he presents as "notions, texts, individual persons, groups of persons or institutions". In this article, religious authorities refers to individuals or groups of people.

Religious authority in Indonesian Islam is very widely dispersed. If we use Bourdieu's perspective, all religions can be seen as competitive fields where agents engage in a constant struggle to gain symbolic capital and ultimately legitimate authority. Out of all the major religions, authority in Islam is particularly dispersed, certainly more than Christianity, as it has no church and no professional class of clergy with an exclusive monopoly on authority (Gaborieau, 2010: 2). Religious leaders in Islam, like Judaism, claim their own authority based on their mastery of religious knowledge (Krämer and Schmidtke, 2006: 5). In practice, there are established routes to gain authority, just like any religion, but they are weakly institutionalised.

Added to this is the particular nature of Indonesian Islam, which arrived in Indonesia without the support of an overarching kingdom with centralised authority, thereby resulting in an accommodation with pre-Islamic beliefs and practices in the different parts of the country.' (Beuhler, 2009: Sidel, 2009). The wide diversity and spread of religious authorities in Indonesian Islam is illustrated by the number of different types of religious leaders. There are, for example, kiai, ajengen, ulama, imam, ustadz, mubaligh, da'i, penyuluh, tengku, buya, guru pesantren and leaders of Muhammadiyah and NU. Some of the differences are geographic, but none have any formal definition. 
The main religious leaders on Java, the kiai, are overwhelmingly independent of any other religious organisation. Their claim to NU membership is based on shared religious practices, but to all intents and purposes they are independent from any central control. Traditionally, they derive their authority from leadership of religious schools (pesantren), which tend to be family property passed down through each generation and financially self-sufficient. This compares to Sunni Middle Eastern countries where prominent ulama are "paid officials administering mosques in the towns and teaching at state-sponsored religious schools." (Hirikoshi, 1984: 77). Such independence tends towards sharper competition. In addition, individual kiais have their own loyal followers (Turmudi, 2003), attracted by their personal charisma, leading to a system of authority which is based on personal characteristics and therefore temporary and ultimately unstable (Hirikoshi, 1984: 88). From this already fragmented basis of religious authority, mass urbanisation heralded the further development of an urban Muslim professional class (Jabali and Subhan, 2007) and, with it, the proliferation of new dakwah organisations with their own religious leaders (Ichwan and Meuleman 2002).

Just as the print revolution in the $20^{\text {th }}$ century opened up access to new written sources of authority (Burhanudin, 2010), so in the last ten years the growth of religious programming on TV and other electronic media has meant the entrance of a new breed of media-savvy preachers. A production house originally established to circulate the teachings of one of the big national religious personalities, Aa Gym, has developed into a television station producing religious themed talk shows, reality shows, soap operas and documentaries (Anwar, 2009). Now, every TV station has some form of religious programming, whereas under Soeharto it was limited to controlled, and largely lifeless, shows on the state channel TVRI. And they are very popular - according to research by the Indonesian Broadcast Commission (KPI) in 2011, "tayangan dakwah" has amongst some of the highest viewing figures of all TV programmes (Anonymous, 2011d).

It seems that this new development is having some effect on what Hirikoshi called "the parochial nature of each ulama's authority." (1984: 80). Where she saw in the 1970s a new generation of ulamas without strong family ties broadening their network from the regional to the national scale (p.89), the spread of electronic media must surely be speeding up this process. Prijosusilo (2012) characterizes it as a "brain drain" where young NU cadres increasingly eschew the deep involvement of past kiais in village life, choosing instead to "sell Islam" in Jakarta's TV studios and seminars around the country. Although Modernist urban Islamic groups have for decades made good use of the media opportunities that were available to them, Burhanudin (2005) considers this to be a new development for the mainly rural traditionalists. An increasing use of the media also means that religious leaders can gain large followings without traditional ties to broad local bases. These developments can only increase what was always a very competitive field. What does all this mean in relation to the Ahmadiyah issue? I do not suggest that the new generation of media savvy preachers all take a radical stance. On the contrary, many of the most popular religious programmes are entertainment - soap operas or 
beauty programmes. Indeed MUI has been very vocal in its rejection of the subject of religious themed films, many of which are horror movies with "mystical" leanings.

Rather, the point is that multiple sources of authority mean many different opinions on religious matters, and a continuous process of group splintering and power plays which is a fertile backdrop for the most vociferous radicals. For example, the 2005 MUI conference which brought the Ahmadiyah issue strongly back into the public domain was characterised by a struggle between two camps in NU headed by Abdurrahman Wahid and Hasyim Muzadi. The two had fallen out the previous year over the 2004 national elections when Muzadi accepted the nomination as Megawati's running mate against Wahid's younger brother who was running as Vice president on the Wiranto ticket. When Wahid lost the battle to eject Muzadi from his position as NU chairman at an NU meeting in 2004, the stage was set for Muzadi to claim his role as a leading proponent of conservative Islam in relation to the liberal stance of Wahid's camp. This dynamic played out in the 2005 MUI conference when NU posted no objection to the fatwa against liberalism, despite its credentials as a liberal and plural organisation. (Setara, 2010:126).

Indonesia's Islamic organisations have always been subject to splits, but as sources of religious authority have proliferated, and to some extent broken free from their geographical moorings, this has accelerated. Even the country's new radical groups struggle to maintain a coherent organisation. Two of the most popular, FPI, and FUI have also been subject to damaging splits, which, like NU, are related to the political affiliations of their various leaders (Setara, 2010:126).

Under such fragmenting pressures, an issue like Ahmadiyah can serve as a powerful lightning rod around which different constituencies group. Heresy is an idea which is relatively simple to grasp and serves the sound bite culture of modern media, demonstrations and other orations. In addition, it is highly symbolic in a situation where religious leaders derive their authority from social recognition rather than institutional hierarchy and so rely on symbols to prove their status. Anti-Ahmadiyah sentiment can also be found among religious leaders from across the traditional modernist divide, serving as a way to create cohesion among the disparate traditions of Indonesian Islam.

An important implication of such an analysis is that it is only partially true to say that Indonesian Islam has become more conservative in recent years. For, although there has certainly been a turn towards religious conservatism, this has occurred in a much more complex landscape than the usual moderate versus radicalist narratives suggest. Any rise in religiously conservative voices must be understood as part of an increase in very many other different voices. 


\section{Conclusion}

This paper has argued that a full understanding of the recent increase in antiAhmadiyah sentiment should include some reference to the dynamics of political and religious authority. It has shown how charges of heresy have historically been used to consolidate a centralized political authority and the ways in which the antiAhmadiyah campaign has supported fragments of the New Order state to claw back some of their lost powers. This is all set against a backdrop of increased competition among religious authorities and a crisis of religious identity.

There are, of course, much more straightforward ways of understanding antiAhmadiyah agitation. At the local level, it has become a way for those seeking public office to declare their religious credentials, serving much the same purpose as the pro-sharia regulations that were popular from 2001 - 2006 (Bush, 2008). There are also many theories surrounding the national level political calculations which have allowed the intimidation to continue. Reasons why President Yudhoyono has supported anti-Ahmadiyah regulations range from a fear of public reaction (ICG, 2008: 16), to a conspiracy of his political enemies to make him look weak (Anonymous, 2011c) and his need for support from Islamic parties in parliament (ICG, 2008: 15). A political trade-off with MUI also seems likely, with the president himself stating at the 2005 MUI conference that "the government needs support from the MUI in peacefully settling the separatist violence in Aceh, as well as help persuading the public to reduce fuel consumption during our problems with the fuel supply and fuel subsidy" (Witular, 2005).

International politics has also undoubtedly played a role in the anti-Ahmadiyah discourse. The sect, whose headquarters are in London, has often been represented as having a special relationship with Western powers from its birth in North West India where its founder sometimes praised British rule and sought its protection when under threat. Because of the problems that Ahmadiyah has encountered in Pakistan, India and some Middle Eastern countries, the issue also serves the interests of those who try to unite the very disparate Islamic communities around the world. Ahmadiyah is the perfect foil in a conspiratorial narrative of the West versus Muslims.

However, this article calls for more analyses of current religious freedom abuses to draw on the established historical and sociological traditions of heresiology which treat heresy discourses as attempts to demarcate community boundaries, or maintain social cohesion. The current academic literature tends to adopt the conventions of human rights organisations, but there is explanatory value beyond describing actors and contemporary political machinations or comparing legal norms. To be sure, religious freedoms are being curtailed and it is important work to draw attention to that, but because heresy discourses are fundamentally about imposing authorities, it is hard to really understand what is happening without reference to their dynamics. 


\section{References}

Aglionby, John (2005) 'The price of democracy', Guardian, October 32005. http://www.guardian.co.uk/world/2005/oct/04/indonesia.comment (accessed March 10, 2013).

Ali (2007), 'Tanpa koordinasi Pakem, pasal penodaan agama dalam KUHP impoten, Hukumonline, October 26 2007, http://hukumonline.com/berita/baca/hol17865/tanpa-koordinasi-pakem-pasalpenodaan-agama-dalam-kuhp-impoten (accessed March 10, 2013).

Ali, Muhamad (2008), 'Islam in Southeast Asia', in Jorgen Baek Simonsen, ed, Politikens Bog Om Islam, Politikens Forlag, Denmark, pp 315-347. English Translation: https://www.eastwestcenter.org/fileadmin/resources/education/asdp_pdfs/asdp_p dfs_2011/NehRead_Ali_Seast_Asia.pdf (accessed March 10, 2013).

Amal, Taufik Adnan and Samsu Rizal Panggabean (2004), Politik Syariat Islam: dari Indonesia hingga Nigeria, Pustaka Alvabet, Jakarta.

Amnesty International (2011), 'Indonesia: open letter on human rights violations against the Ahmadiyya in West Java', Ref: TG ASA 21/2011.034, 14 October 2011 http://www.amnesty.org/en/library/asset/ASA21/032/2011/en/59e25ae4-c0fd4b4f-9ed8-132ef548bdc2/asa210322011en.html (accessed March 10, 2013).

Anonymous (2005), 'Pakem diaktifkan kembali', Kompas, 15 September 2005.

Anonymous (2006), 'Muspida itu peninggalan Orba', Kompas, 27 November 2006.

Anonymous (2011a) 'Hasyim Muzadi: segera bubarkan Ahmadiyah', Republika, 22 February 2011, http://www.republika.co.id/berita/breakingnews/nasional/11/02/22/165498-hasyim-muzadi-segera-bubarkan-ahmadiyah, (accessed 29 January 2012).

Anonymous (2011b), 'NU dukung larangan Ahmadiyah,' Suara Merdeka, 28 March 2011, http://suaramerdeka.com/v1/index.php/read/news/2011/03/28/81451/NUDukung-Larangan-Ahmadiyah (accessed 29 January 2012).

Anonymous (2011c), 'Retired generals backing hardliners in plot to topple SBY: Al Jazeera', The Jakarta Post, 22 March 2011, http://www.thejakartapost.com/news/2011/03/22/retired-generals-backinghardliners-plot-topple-sby-al-jazeera.html, (accessed March 12, 2013).

Anonymous (2011d), 'Tayangan dakwah favorit pemirsa televise,' Republika, 22 August 2011, 
http://www.republika.co.id/berita/nasional/umum/11/08/22/lqc2nr-tayangandakwah-favorit-pemirsa-televisi (accessed March 12, 2013).

Awwas, Irfan, S. (2000), Bencana Ummat Islam di Indonesia Tahun 1980-2000, Wihdah Press, Yogyakarta. http://serbasejarah.files.wordpress.com/2010/04/bencanaummat-islam-indonesia-tahun-1980-2000.pdf (accessed March 10, 2013).

Azra, Azyumardi (2006), Islam in the Indonesian World: An Account of Institutional Formation, Mizan, Bandung.

Benda, Harry and Lance Castles (1969), 'The Samin Movement', in Bijdragen tot de Taal-, Land-en Volkenkunde, Vol 125, No 2, pp 207-240.

Bhakti, Ikrar Nusa, Sri Yanuarti and Mochamad Nurhasim (2009), 'Military politics, ethnicity and conflict in Indonesia', Crise Working Paper, No 62, Centre for Research on Inequality, Human Security and Ethnicity, Oxford.

http://www.dfid.gov.uk/r4d/PDF/Outputs/Inequality/wp62.pdf (accessed March $10,2013)$.

van Bruinessen, Martin (1995), 'Shari'a court, tarekat and pesantren: religious institutions in the sultanate of Banten', Archipel 50, pp 165-200.

Buchori, Mochtar and Cornelis Lay (2000), 'Assessing current political developments in Indonesia', Trends in Southeast Asia Series, Institute of Southeast Asian Studies, Singapore.

Burhani, Ahmad Najib (2012), 'Indonesia a failed state? Fate of the Ahmadis shows it could be', Jakarta Globe, 4 August, 2012, http://www.thejakartaglobe.com/commentary/indonesia-a-failed-state-fate-of-theahmadis-shows-it-could-be/535215 (accessed March 12, 2013).

Burhanudin, Jajat (2005), 'Otoritas Keagamaan: Beberapa Pengalaman Islam Indonesia', Dialog: Jurnal Penelitian dan Kajian Keagamaan, Vol 6, No 31, pp 76.

Burhanudin, Jajat (2010), 'Traditional Islam and modernity: some notes on the changing role of Ulama in the early twentieth century', in Ayyumardi Azra, Kees Van Dijk and Nico J G Kapten, eds, Varieties Of Religious Authority, International Institute For Asian Studies-Institute of Southeast Asian Studies, pp 54-72.

Bush, Robin (2008), 'Regional Sharia Regulations in Indonesia: Anomaly or Symptom?', in Greg Fealy and Sally White, eds, Expressing Islam: Religious Life and Politics in Indonesia, Institute of Southeast Asian Studies, Singapore, pp 174-191.

Carrette, Jeremy, R. (2000), Foucault and Religion, London and New York, Routledge. 
Colbran, Nicola (2010), 'Realities and challenges in realising freedom of religion or belief in Indonesia', The International Journal of Human Rights, Vol 14, No 5, pp 678704.

Crouch, Melissa (2009), 'Indonesia, militant Islam and Ahmadiyah: origins and implications', ARC Federation Fellowship 'Islam, Shariah and Governance' , Background Paper Series No 4., University of Melbourne, Melbourne. http://papers.ssrn.com/sol3/papers.cfm?abstract_id=1551645 (accessed March 10, 2013).

Crouch, Melissa (2011), 'Ahmadiyah in Indonesia: a history of religious tolerance under threat?', Alternative Law Journal, Vol 36, No 1, pp 56-57.

Anwar, Marzani (2009), Dakwah di Pentas Media TV: Laporan Hasil Penelitian Balai Penelitian dan Pengembangan Agama, Departmen Agama, Jakarta.

Firmansyah, Ujang (2011), 'Tim Advokasi Jaringan Masyarakat Sipil untuk Perlindungan Warganegara: Presiden dan parlemen harus evaluasi TNI terkait pelanggaran terhadap Ahmadiyah', 14 March 2011

http://www.imparsial.org/id/2010/tim-advokasi-jaringan-masyarakat-sipil-untukperlindungan-warganegara-presiden-dan-parlemen-harus-evaluasi-tni-terkaitpelanggaran-terhadap-ahmadiyah.html (accessed March 10, 2013).

Florida, Nancy K. (1995), Writing the Past, Inscribing the Future: History as Prophecy in Colonial Java, Duke University Press, Durham.

Gaborieau, Marc (2010), 'The redefinition of religious authority among South Asian Muslims from 1919 to 1956' in Ayyumardi Azra, Kees Van Dijk and Nico J G

Kapten, eds, Varieties Of Religious Authority, International Institute For Asian StudiesInstitute of Southeast Asian Studies, pp 1-16.

Gillespie, Piers (2007), 'Current issues in Indonesian Islam: analysing the 2005 Council of Indonesian ulama fatwa no. 7 opposing pluralism, liberalism and secularism', Journal of Islamic Studies, Vol 18, No 2, pp. 202-240.

Hefner, Robert W. (2005), 'Muslim democrats and Islamist violence in post-Soeharto Indonesia, in Robert W. Hefner, ed, Remaking Muslim Politics: Pluralism, Contestation, Democratization, Princeton University Press, Princeton, NJ, pp 273-301.

Hirikoshi, Hiroko (1984), 'Corporate and non-corporate features of Muslim learned men in West Java', Social Compass, Vol 31, No 1, pp. 75-89.

Honna, Jun (2011), 'The legacy of the New Order military in local politics: West, Central and East Java', in Edward Aspinall and Greg Fealy, eds, Soeharto's New Order 
and its Legacy: Essays in Honour of Harold Crouch, Asian Studies Series, ANU E-Press, Canberra, pp 135-150.

Hooker, Barry, M. (2003), Islam: Social Change through Contemporary Fatawa, University of Hawai'i Press, Honolulu.

Hudiyanto, Wawan (2011) 'Harus mengacu Keppres No 10 Tahun 1986 DPRD soroti pemberian honor kegiatan Muspida Plus', Suara Merdeka, 15 July 2011. http://www.suaramerdeka.com/v1/index.php/read/news/2011/07/15/91062/DP RD-Soroti-Pemberian-Honor-Kegiatan-Muspida-Plus (accessed 10 October 2012).

ICG: International Crisis Group (2008), 'Indonesia: implications of the Ahmadiyah decree', Asia Briefing No. 78, International Crisis Group, Jakarta. http://www.crisisgroup.org/en/regions/asia/south-east-asia/indonesia/B078indonesia-implications-of-the-ahmadiyah-decree.aspx (accessed March 10, 2013).

Ichwan, Moch Nur (2005), 'Ulamas, State And Politics: Majelis Ulama Indonesia After Suharto Islamic', Law And Society, Vol 12, No 1, pp 45-72.

Ichwan, Moch Nur (2011), 'Official ulema and the politics of re-islamization: the majelis permusyawaratan ulama, shariatization and contested authority in post-new order Aceh', Journal of Islamic Studies, Vol 22, No 2, pp 183-214.

Ichwan, Moch Nur and Johan Hendrik Meuleman (2002), 'Islam in Indonesia: dissemination of religious authority in the twentieth and early twenty-first centuries', Islam in Indonesia Programme, Scientific Programme Indonesia-Netherlands, http://www.knaw.nl/Content/Internet_KNAW/publicaties/pdf/20031027_3.pdf (accessed March 10, 2013).

Ikrar Nusa Bhakti, Hargyaning Tyas, Heru Cahyono, Japanton Sitohang, M. Hamdan Basyar, Moch. Nurhasim, Riza Sihbudi and Sri Yanuarti (1999), Tentara yang Gelisah: Hasil Penelitian Yipika tentang Posisi ABRI dalam Gerakan Reformasi, The Indonesian Institute of Sciences, Mizan, Bandung.

Ismail, Rachmadin (2010), 'KPK telusuri pemberian honor bagi Gamawan Fauzi', detiknews, 1 February 2010, http://news.detik.com/read/2010/02/01/090744/1289968/10/\%7BURL3\%7D (accessed 10 October 2012).

Jabali, Fuad and Arief Subhan (2007), 'A new form of contemporary Islam in Indonesia' in Rizal Sukma, Clara Joewono, eds, Islamic Thought and Movements in Contemporary Indonesia, Centre for Strategic and International Studies, Jakarta, pp 5478.

Jansen, David (2008), 'Relations among security and law enforcement institutions in Indonesia', Contemporary Southeast Asia, Vol 30, No 3, pp 429-54. 
Kaptein, Nico J.G. (2004), 'The voice of the 'ulamâs: fatwas and religious authority in Indonesia', Archives de Sciences Sociales des Religions, No 125 (January - March) pp $115-130$.

van Klinken, Gerry and Joshua Barker (2009), 'Reflections on the state in Indonesia', in Gerry van Klinken and Joshua Barker, eds, State of Authority: The State in Society in Indonesia, Cornell University Southeast Asia Program, Ithaca, N.Y, pp 17-45.

Krämer, Gudrun and Sabine Schmidtke (2006), 'Introduction: religious authority and religious authoritiesiin Muslim societies: A Critical Overview', in Gudrun Krämer and Sabine Schmidtke, eds, Speaking for Islam: Religious Authorities in Muslim Societies, Brill, Leiden, pp 1-15.

LBH (Lembaga Bantuan Hukum) and Kontras (Komisi Untuk Orang Hilang dan Tindak Kekerasan) (2008), Laporan Investigasi : Kekerasan terhadap Jama'ah Ahmadiyah di Manislor, Kuningan, Jawa Barat \& Lombok, NTB, LBH- KontraS, Jakarta.

Lev, Daniel S. (1972), Islamic Courts in Indonesia: A Study in the Political Bases of Legal Institutions, University of California Press, Berkeley.

Marcinkowski, Christoph (2010), Shi'ite Identities: Community and Culture in Changing Social Contexts, LIT Verlang, Berlin.

Mashadi, (2010), 'NII, Komando Jihad dan Orde Baru: the untold story, Era Muslim, 5 August 2010, http://www.eramuslim.com/berita/tahukah-anda/nii-pks-danhelmi-aminuddin-the-untold-story.htm\#.US_jbDDYjnE (accessed March 12, 2013).

Masud, Abdurrahman (2009), 'Menyikapi keberadaan aliran sempalan', Dialog: Jurnal Penelitian dan Kajian Keagamaan, Vol 32, No 68, pp 16-24.

Mietzner, Marcus (2006), 'The politics of military reform in post-Suharto Indonesia: elite conflict, nationalism, and institutional resistance, Policy Studies, No 23, EastWest Center, Washington, http://scholarspace.manoa.hawaii.edu/bitstream/handle/10125/3497/PS023.pdf?s equence $=1$ (accessed March 10, 2013).

Mudzakkir, Amin (2007), 'Kaum minoritas dan Islam politik pasca orde baru: diskriminasi dan persekusi terhadap Jemaat Ahmadiyah Indonesia (JAI) di Cianjur, Jawa Barat', Swara Politika : Jurnal Politik dan Pembangunan, Vol 10, No 2, pp 93-105.

Muryadi, Wahyu (2005), Ahmadiyah: Keyakinan yang Digugat, Pusat Data dan Analisa Tempo, Jakarta.

Nasution, Khoiruddin (2008), 'Fatwa Majelis Ulama Indonesia (MUI) on Ahmadiyah', Millah: Jurnal Studi Agama, Vol 7, No 2, pp 75-91. 
Olle, John (2009), 'The Majela Ulama Indonesia versus 'heresy': the resurgence of authortative Islam', in Geert Arend van Klinken and Joshua Barker, eds, State of Authority: The State in Society in Indonesia, Cornell University Southeast Asia Program, Ithaca, N.Y, pp 95-116.

Patty, Semuel Agustinus (1986) Aliran Kepercayaan: A Socio-Religious Movement in Indonesia, $\mathrm{PhD}$ Thesis, Washington State University.

Platzdasch, Bernard (2011), 'Religious freedom in Indonesia: the case of the Ahmadiyah,' ISEAS Working Paper: Politics \& Security Series, No. 2, Singapore. http://www.iseas.edu.sg/documents/publication/ps22011R.pdf (accessed March $10,2013)$.

Porter, Donald (2002), Managing Politics and Islam in Indonesia, Routledge, New York.

Prijosusilo, Bramantyo (2012) 'Religious brain drain in Java villages', Strategic Review, The Indonesian Journal of Leadership, Policy and World Affairs, 15 February 15, 2012, http://www.sr-indonesia.com/2011-08-09-22-09-10/commentaries/146religious-brain-drain-in-java-villages (accessed March 12, 2013).

Purwanto, Wawan H. (2008), Menusuk Ahmadiyah, CMB Press, Jakarta.

Reid, Anthony (1993), 'Islamization and Christianization in Southeast Asia: the critical phase, 1550-1650', in Anthony Reid, ed, Southeast Asia in the Early Modern Era: Trade, Power, and Belief, Cornell University Press, Ithaca, pp $151-79$.

Reid, Anthony (1995), 'Continuity and change in the Austronesian transition to Islam and Christianity', in Peter Beilwood. James J. Fox, and Darrell Tryon, eds, The Austronesians: Historical and Comparative Perspectives, Australian National University, Canberra, pp 314-22.

Ricci, Ronit (2011), Islam Translated: Literature, Conversion, and the Arabic Cosmopolis of South and Southeast Asia, University of Chicago Press, Chicago.

Ricklefs, Merle C. (1979), 'Six centuries of Islamization in Java', in Nehemia Levtzion, ed, Conversion to Islam, Holmes and Meier, New York, pp 100-28 .

Ricklefs, Merle C. (2008), A History of Modern Indonesia since 1200, Stanford University Press, Stanford.

Riddell, Peter G. (2001), Islam and the Malay-Indonesian World: Transmission and Responses, University of Hawaii Press, Honolulu.

Ridho, Kholis (2008), 'Memperbincangkan otoritas keagamaan dalam Islam', Dialog: Jurnal Penelitian dan Kajian Keagamaan, Vol 31, No 65, pp 52 - 65. 
Rosidin, Didin Nurul (2010), 'Islam, Ahmadiyah and the Government: Unresolved Religious Conflicts in Manis Lor Kuningan, West Java', Teologia: Jurnal Ilmu-ilmu Ushuluddin, Vol.21, No.1, pp 207-226.

Setara (2010), The Faces of Islam 'Defenders', Pustakar Masyarakat Setara, Jakarta.

Setara (2011), Radikalisme Agama di Jabodetabek \& Jawa Barat Implikasinya terhadap Jaminan Kebebasan Beragama/ Berkeyakinan, Desember, SETARA Institut, Jakarta.

Sidel, John T. (2007), Riots, Pogroms, Jihad: Religious Violence in Indonesia, NUS Press, Singapore.

Sidel, John T. (2009), 'The changing politics of religious knowledge in Asia: the case of Indonesia' in Saw Swee-Hock and Danny Quah, eds, The Politics of Knowledge, Institute for Southeast Asian Studies, Singapore, pp. 156-157.

Sihombing, Uli Parulian (2008), Menggugat Bakor Pakem: Kajian Hukum Terhadap Pengawasan Agama dan Kepercayaan di Indonesia, Indonesian Legal Resource Center (ILRC), Jakarta.

Silitonga, Harles (2011), 'NU-Muhammadiyah bahas Ahmadiyah ', Waspada 4 March, 2011, http://www.waspada.co.id/index.php?option=com_content\&view=article\&id=178 818:nu-muhammadiyah-bahas-ahmadiyah\&catid=17\&Itemid=30, (accessed 29 January 2012).

Tanter, Richard (2000), 'The Indonesian intelligence state: characteristics and prospects, paper prepared for the Australian Asian Studies Conference, July 2 - 5, 2000. http://rmit.nautilus.org/publications/indonesian-intelligence.html (accessed March 10, 2013).

Turmudi, Endang (2003), Chapter 4: The social reality of Kiaiship, Section 4.3: The fragmented organisation of Islam, in Struggling for the Umma: Changing Leadership Roles of Kiai in Jombang, East Java, Australian National University, Canberra http://epress.anu.edu.au/islamic/umma/mobile_devices/index.html (accessed 27 September 2011).

Witular, Rendi A. (2005), 'MUI to formulate edicts against 'liberal thoughts' The Jakarta Post, 27 July 2005. http://www.thejakartapost.com/news/2005/07/27/muiformulate-edicts-against-039liberal-thoughts039.html (accessed March 12, 2013).

Zito, George V. (1983), 'Toward a sociology of heresy', Sociological Analysis, Vol 44, No 2, pp 123-130.

Zulkarnain, Iskandar (2005), Gerakan Ahmadiyah di Indonesia, LKIS, Yogyakarta. 